\title{
What Diplomacy in the Ancient Near East Can Tell Us About Blockchain Technology
}

\author{
Chris Berg $^{\dagger *}$
}

\begin{abstract}
A blockchain is an institutional technology-a protocol-that allows for economic coordination between agents separated by boundaries of possible mistrust. Blockchains are not the only technology in history to have these characteristics. The paper looks at the role of the diplomatic protocol at the very beginning of human civilisation in the ancient near east. These two protocols-diplomatic and blockchain-have significant similarities. They were created to address to similar economic problems using similar mechanisms: a permanent record of past dealings, public and ritualistic verification of transactions, and game-theoretic mechanisms of reciprocity. The development of the diplomatic protocol allowed for the creation of the first international community and facilitated patterns of peaceful trade and exchange. Some questions about a generalised 'protocol economics' are drawn.
\end{abstract}

\section{Introduction}

Blockchains are protocols which coordinate economic activity. A protocol is an institution that facilitates trusted communication between agents separated by boundaries of possible mistrust-boundaries which can be technical (different operating systems and imperfect transmission networks), geographic (global distance), political (states and national borders), or cultural (different languages, ethnicities or ideologies). A successful protocol creates a distributed system-or network - which agents enter or exit by adhering to the rules of the protocol.

In this sense, blockchain protocols are one recent advance in a historical line of protocols that date back to the beginnings of written civilisation. The ancient near east between 2400 and $1200 \mathrm{BCE}$ saw the construction of a complex system of international relations between a large number of proto-states. To give some sense of the size and complexity of this system, documents found in the Mari archive in Syria identify 160 separate kings in the region over a period of 30 years. ${ }^{1}$

Scholars have been able to partly reconstruct the system via the discovery of libraries of clay tablets containing diplomatic letters, dispatch orders, and treaties. Sometime around 2340 BCE a letter was sent by the king of Ebla, a kingdom in today's northern Syria, to the king of Hamazi, an as-yet-undiscovered city or kingdom likely somewhere in northern Iraq. ${ }^{2}$ This is the first diplomatic letter which has been uncovered but certainly not the first instance of

${ }^{\dagger}$ Chris Berg (christopherberg@rmit.edu.au) is a Postdoctoral Fellow at the School of Economics, Finance and Marketing, and Fellow at the RMIT Blockchain Innovation Hub, RMIT University.

*1Am8ajXSTp4CESsPvUW1VetxK33N9s2b36 
diplomacy. The text of the Hamazi-Ebla letter makes it clear that the kings, and the scribes and officials who produced the document, were following a diplomatic protocol that had been long developed and was highly formalised. This protocol enabled interactions between disparate groups which in many cases spoke different languages. The protocol sought to ensure that communications and treaties between them were done as securely, as certainly, and as clearly as possible under the institutional and technological limitations of the ancient world.

This paper examines how this ancient diplomatic protocol helps us understand the institutional economics of blockchains. By comparing the protocol that facilitated interactions between these ancient cities and kingdoms we can see highlight economic features of the blockchains that are currently underappreciated. Both blockchain protocols and diplomatic protocols raise the costs of opportunistic behaviour through a combination of a permanent record of past dealings, public and ritualistic verification of transactions, and game-theoretic mechanisms of reciprocity. As new powers such as Egypt entered the diplomatic space the protocol had to be adapted to meet the new structural conditions. How protocols adjust to growing user bases (some with greater control over the protocol than others) is of particular significance considering the challenge of changing a distributed protocol in response to scaling problems and (potentially) dominant players and the challenge of integrating the blockchain into pre-existing economic activities.

The analysis of blockchains as an economic technology is in its nascent stage. ${ }^{3}$ Here we follow an institutional cryptoeconomics approach. ${ }^{4}$ This approach applies the transaction cost school of Ronald Coase and Oliver Williamson to the study of the distributed ledger technologies. ${ }^{5}$ Blockchains significantly reduce transaction costs through a combination of cryptography, distributed computing, append-only databases, and a consensus algorithm. The institutional cryptoeconomics approach describes a blockchain as an institutional technology that can be used to create new economies - that is, opportunities for spontaneous organisation. Blockchains are a coordinating institution to facilitate decentralised interaction. (A parallel but complementary analytical framework looks at blockchains as a governance mechanism for political communities. ${ }^{6}$ )

Ancient diplomatic protocol was a similar institutional technology which allowed for political and economic exchange at the very beginning of human civilisation. Diplomatic protocol provides the "stage directions" or etiquette of international diplomacy - a series of rules, mostly unwritten, which govern interactions between states in a way that is intended to reduce the risks of conflict and miscommunication. ${ }^{7}$ These can involve gift exchange, standardised language, ritualised greetings, adherence to strict hierarchies of precedence, codes of hospitality, and coded and deferential language. The conclusion of a treaty was brought about through further ritual and ceremony. The richness and constraints of ancient international diplomacy has been used to explore economic theory before. The intergovernmental relationships shown in ancient tablets have yielded game-theoretic insights. ${ }^{8}$ The relative consistency of the diplomatic protocol itself has been used to draw out the strength of relationships in the ancient near east: Raymond Cohen has looked at kinship diplomacy, and Ellen F. Morris has used the obsequiousness in the Egyptian Amarna letters to map out the strength of the Egyptian empire's control over the near east. ${ }^{9}$

Unsurprisingly this is the first paper to relate the institutional economics of blockchains to diplomatic protocol. Part 2 of this paper explores the diplomatic protocol in light of what we know about the economics of blockchain, as a facilitator of spontaneous order. Part 3 looks at 
how the protocol changed in order to adjust to changes in the space of near eastern geopolitics. Part 4 concludes.

\section{Diplomatic Protocol in Light of the Economics of Blockchains}

The ancient near east had a good understanding of the problems of insecure and unverified communication. The earliest writings we have are primarily administrative documents and word lists for the teaching of writing. ${ }^{10}$ Writing and pre-writing emerged as a memory tool-a technology for information storage in the context of administration. ${ }^{11}$ Nevertheless, it is indicative of the cultural significance of writing for interstate communication that two separate Sumerian stories associate the invention of writing with the invention of the diplomatic letter. ${ }^{12}$ The first story postdates the Hamazi-Ebla letter by at least three centuries. Enmerkar and the Lord of Arratta tells the story of the development of the international system, as cities which faced each other as hostile strangers established trade relationships through diplomacy. ${ }^{13}$ In this story, writing developed to reduce the high cost of communication between Enmerkar, king of the Iraqi city of Uruk, and Iranian city of Aratta. Their verbally-relayed correspondence had become so unwieldy that the messengers could not remember the full messages:

Because the messenger was heavy of mouth and could not repeat [the message] Enmerkar ... patted the clay and wrote words on it as if it were a tablet. At that time writing on clay did not exist but now, as a result, when day broke, thus it was. $^{14}$

The result of this innovation was successful communication with the ruler of Aratta.

But the second story was a warning about how communication could go bad. This story concerns the rise of Sargon, later to become ruler of all Mesopotamia. At this time Sargon is a cupbearer to Ur-Zababa, ruler of the city of Kish, but has been chosen by the gods as a new great leader. Ur-Zababa sought to have his young official killed by a rival king to whom he had dispatched Sargon:

At that time writing on tablets indeed existed but enclosing them in clay [that is, an envelope] had not yet been invented. King Ur-Zababa, for Sargon, creature of the gods, wrote a tablet that would cause his [the bearers'] death. He dispatched it to [King] Lugalzagesi in Uruk. ${ }^{15}$

This story is unfortunately fragmentary. It seems that Sargon broke open the envelope in which the letter was enclosed and evaded execution, perhaps by altering the letter's contents. ${ }^{16}$ It underlined for the Sumerians the "ideological danger of written communications: letters can be falsified, altered, or simply lost."17

These stories give us a picture of diplomatic relations long established prior to the advent of writing. Furthermore our limited sources mean that unfortunately we cannot fully see how the states groped towards the protocol as it first appears to us. Nevertheless, we can see some traces of this process. The Hamazi-Ebla letter is written in the language of Ebla. ${ }^{18}$ By the second millennium Akkadian — the language of Sargon's Akkadian empire- had assumed a 
role as the international language of diplomacy. This was the case long after Akkadian domination ended and even in communications when both parties did not speak Akkadian firsthand. ${ }^{19}$

Embedded in Mesopotamian diplomatic protocol was a strict hierarchy that governed how messages were communicated. The Hamazi-Ebla letter is structured programmatically:

Thus [says] Ibubu, the steward of the palace of the king to the envoy: I am [your] brother and you are [my] brother. What is [appropriate] to brother[s]: whatever desire you express, I shall grant and you, [whatever] desire [I express], you shall grant.

May you deliver to me the finest quality equids. You are [my] brother and I am [your] brother. [Therefore I], Ibubu, have given [you], the envoy, ten [wagon] ropes, and two boxwood wagons.

Jirkab-Damu, the king of Ebla is the brother of Zizi, the king of Hamazi; Zizi, the king of Hamazi, is the brother of Jirkab-Damu, king of Ebla.

Jirkab-Damu, the king of Ebla, and the scribe Tira-ii have dispatched [the goods] to the envoy. ${ }^{20}$

First, it establishes the sender-Ibubu, a high court official of Ebla - and the receiver"the envoy" at Hamazi. The second step establishes a hierarchical order. The officials of Ebla and Hamazi were not siblings. Mesopotamian diplomacy was structured around a fictitious familial relationship. The great kings all addressed each other as brothers. This conceit was a mechanism to signal and build trust-brothers were not merely equals but coexisted in deep, reciprocal relationships: "whatever desire you express, I shall grant and you, [whatever] desire [I express], you shall grant." As Amanda H. Podany argues, such kinship diplomacy was an effort to provide order in an otherwise potentially anarchic world. ${ }^{21}$ In later eras, this flat hierarchy became more complex: vassals would be 'sons' to their great king 'fathers,' 'brothers' to kings of different ranks, and 'fathers' to those further below them on the pecking order. ${ }^{22}$

Fictive kinship provided a coded structure in the message that shaped the nature of the communication. We can track the rise and fall of certain city-states as they move up and down this hierarchy. ${ }^{23}$ In the cache of texts found at the Mari archive changes in status were signalled by a further, complementary metaphor, relating to the hem of garments. New vassalage relationships were described as "seizing" the hem of the superior king. New allies tied their hems together, rebels "severed" hems, and to end an alliance was to "release" the hem. ${ }^{24}$

The Hamazi-Ebla letter then goes on to detail the terms of the transaction, which involved the trade of horses in return for ropes and wagons. Finally, the letter ends with what can only be described as metadata. First, an authorisation that affirms that what is being done by the officials was being done in the name of the relevant kings, and clarified or reiterated the kinship relationship between the kings of Ebla and Hamazi. Second, it concludes with a dispatch 'signature,' confirming the execution of the transaction and introducing a fifth individual, Tira-ii, the scribe who wrote the message as a final confirmation of its authenticity. 
From an information transfer perspective this is a highly inefficient message. For example, it repeats its filial affirmations three separate times; it introduces five people for what is a transaction between two. But these redundancies have instrumental functions. They are performed as a type of diplomatic ritual. Ritual is repetitive, socially standardised symbolic behaviour. ${ }^{25}$ Ritual is a form of costly signalling that imposes seemingly unproductive costs on participants to reduce opportunistic behaviour. ${ }^{26}$ It is a form of communication used when the chances of miscommunication are high. ${ }^{27}$ Ritual has high opportunity cost-ritual communication takes up a large amount of the Hamazi-Ebla letter-and it requires a high degree of investment to learn and deploy. That high cost is performative, endorsing and building trust between two autonomous political entities who could as easily be adversaries as allies. ${ }^{28}$ Failure to observe the detail of diplomatic ceremony could lead to serious diplomatic incidents. ${ }^{29}$ Treaties were even more heavily ritualised. These documents were likely read aloud in public, in the presence of third party emissaries, and in the presence of the gods of both parties. ${ }^{30}$ Gifts were exchanged as part of the trust mechanism and as a mutual reward for the maintenance of future conduct. Failure to ensure gifts were of equivalent value could lead to a diplomatic crisis.

In this context, blockchain validation algorithms are ritualistic costly signals. Blockchain mining is a proof of work method of publicly validating transactions in an environment that would otherwise reward double spending. It is deliberately costly. A June 2016 estimate of the cost of the Bitcoin proof of work found that it consumed around US\$50,000 of energy an hour, and concluded that the resources devoted to mining were "large, wasteful, but necessary." 31 Miners recoup this cost with a reward for finding valid blocks. Alternative blockchain consensus mechanisms have to deploy similarly costly signalling mechanisms. For example, proof of stake algorithms have to ensure that it is costly for block-generators to sign both sides of a fork, resolving what has been termed the "nothing at stake" problem. ${ }^{32}$ Resolving the nothing at stake problem involves a putting up a 'bond' of tokens that is forfeit in the case of rule breaking. Vitalik Buterin has described the mechanism as "security comes from putting up economic value-at-loss. ${ }^{, 33}$ Both diplomatic ritual and blockchain validation mechanisms appear wasteful, obscure and unproductive; but both play an essential role in the creation of trust between (potential) adversaries and the validation of communication.

Ancient messages can also be seen as a permanent and distributed ledger of alliances and economic relationships. The letters and treaties were not secret. Their validity was affirmed through public proclamation and display. They were append-only: stored for permanency and made available in vast tablet libraries for interested parties and later generations to inspect and verify. The record-keeping aspirations of the ancient near east are evident throughout the tablet archives. It is possible that not all transaction records which survive were have been intended to be kept. Many tablets apparently intended for temporary use were only baked into permanency when violent fires destroyed these archives; nevertheless, it is clear that many diplomatic and summary account tablets were intentionally baked and stored. ${ }^{34}$

Finally, early diplomatic texts also show concern to relate new diplomatic 'transactions' back to the history of the ledger. This is most evident in the nearly three dozen Hittite treaties with Hittite vassal states that survive. These treaties adhere to a strict formula with little variation. A preamble lists the name, title and genealogy of reigning Hittite king. Then, before the details of the diplomatic agreement, the treaty provides an often-lengthy historical prologue; that is, an accounting of the previous relationships between the Hittite king and the vassal state. ${ }^{35}$ These introductions were of course highly partial and propagandistic, but they provided, within the limits of ancient governance, a chain of diplomatic relations between 
multiple royal administrations. As Amnon Altman writes, the Hittite historical prologue was "designed to present a legal argument or a set of such arguments, justifying the imposition of obligations on the second party, and depriving that party of the ability to contest the validity or legality of the treaty." 36 In other words, the historical prologues acted as consensus engines in the absence of a third party enforcement mechanism - one of the key institutional features of a blockchain. ${ }^{37}$

\section{Expanding the Diplomatic Space}

Institutional cryptoeconomics considers blockchain technology as an economic coordination mechanism that should be considered a new competitor to the existing economic institutions of capitalism: markets, hierarchical firms, relational contracting, or governments. ${ }^{38}$ Which economic problems are appropriate use cases for a blockchain is a less a technological question than a question about comparative institutional costs. ${ }^{39}$ Here ancient diplomacy also provides a relevant historical example of such an institutional choice being made, as a potentially dominant geopolitical actor with a preference for hierarchical relationships chose to participate in the non-hierarchical international network. The protocol lowered the costs of non-hierarchical relational contracting for dominant and non-dominant parties, allowing for political and economic coordination to be decentralised.

The Syrian-Mesopotamian world was shaken by the introduction of the large and wealthy Egyptian empire - a potential dominant player-in the mid-second millennium. Egyptian international relationships and Syrian-Mesopotamian relationships were institutionally distinct. Egyptian relationships were hierarchical. Subordinate kings swore oaths to the Egyptian ruler, but the Egyptian did not offer an oath in response. ${ }^{40}$ Egyptian kings believed themselves to be rulers of the world, and that their relationships with distant powers came in the form of tributes rather than exchange. In the institutional framework, hierarchies (such as firms and governments) are intended to limit opportunistic behaviour (rule-breaking) by enforcing incomplete (that is, non-comprehensive) contracts. ${ }^{41}$ By contrast, SyrianMesopotamian relationships were relational: reciprocal contractual relationships which imposed obligations on both parties to the agreement governed by understood norms. ${ }^{42}$

Egypt's integration into the international system began with an agreement of peace between the king of the Mittani, an empire which had come to dominate the area around Syria, and Amenhotep II of Egypt after the ninth year of the latter's reign. After the peace, the Egyptian king addressed himself as brother to the other great kings, participated in the exchange of equivalently valued gifts, communicated in Akkadian, intermarried, and accepted treaties as a geopolitical equal. Amanda H. Podany emphasises how strikingly different the new peace was from Egyptians' perspective - to the extent that Amenhotep seems to have tried to obscure the exchange relationship from his subjects. ${ }^{43}$ The fact that diplomacy was conducted in the alien language of Akkadian would have helped.

The exact motives that brought the Egyptians and Mittani to this peace are unfortunately undocumented. Nevertheless, we can draw some comparative institutional conclusions that parallel implementation questions faced by potential blockchain use-cases. For Egypt, war with distant Mittani was unlikely to bring the sort of wealth that could be gained from tradeparticularly access to lapis lazuli and tin. From the Mittani side, the high cost of ongoing military action with Egypt compared poorly against the possibilities of obtaining luxuries 
from that distant empire. Presumably Mittani was worried about whether to trust its new friend Egypt but these concerns would have been mitigated by treaty provisions, both ritual (such as gift exchange and intermarriage) and practical (settled territorial boundaries and deeper trade networks). ${ }^{44}$ In the event, Egypt's entry into the international system sparked further rounds of treaties as the other Syrian-Mesopotamian powers established Egypt as a node in the network. Given Egyptian self-belief in their own dominance, acceding to the diplomatic protocol as an equal among many would have been costly. That cost was lost economic rents - such as political power and tribute-but was exceeded by the gains from joining the network. The diplomatic protocol facilitated trust in an environment not otherwise conducive to decentralised exchange even when one actor was disproportionately powerful.

\section{Conclusion}

It is no coincidence that the first (known) international system was also coincident with the first protocol. A protocol enables exchange-diplomatic, economic, contractual-between groups divided by boundaries of possible mistrust. This paper has drawn a relationship between a blockchain protocol and the diplomatic protocol of the early near east. What does this suggest for us about blockchain technology? The economic characteristics of the blockchains are distinct from its technological characteristics. The economic value of the blockchain is an institutional rather than technological one. ${ }^{45}$ An economics of blockchain protocols should bring us to an economics of protocols in general-the institutional technologies that allow for the creation of networks.

Blockchains consist of a suite of technologies that create trust and information permanence. ${ }^{46}$ Diplomatic protocol is also a suite of technologies (rituals, ceremonies, and norms) that seek to create trust, commitment, and information permanence that reduces opportunistic behaviour. To treat blockchains as one protocol among many protocols raises questions for further research and protocol applications. What are the essential economic attributes of a protocol-as-institution? That is, what economic and technological features are necessary for the creation of an efficient protocol? The answer to these questions will provide not only new guidance for possible blockchain use-cases and implementations, but more fundamentally should help develop a path into the institutional structure of the cryptoeconomy.

\section{Acknowledgments}

The author would like to thank Jason Potts, Darcy Allen, Sinclair Davidson, Aaron Lane, Matthew Lesh and two anonymous reviewers for their valuable suggestions.

\section{Notes and References}

\footnotetext{
${ }^{1}$ Foster, B. R. "Water under the Straw: Peace in Mesopotamia," in K. A. Raaflaub (Ed.) War and Peace in the Ancient World. Maldon, Massachusetts: Blackwell Publishing 66-80 (2007)
} 
${ }^{2}$ Shea, W. H. "The Form and Significance of the Eblaite Letter to Hamazi," Oriens Antiquus 23 143-158 (1984); Podany, A. H. Brotherhood of Kings: How International Relations Shaped the Ancient near East. New York: Oxford University Press 26-28 (2010)

${ }^{3}$ Catalini, C., Gans, J. S. "Some Simple Economics of the Blockchain," Rotman School of Management Working Paper No. 2874598 (2016) https://papers.ssrn.com/sol3/papers.cfm?abstract_id=2874598; Pilkington, M. "Blockchain Technology: Principles and Applications," in F. Olleros, M. Zhegu (Eds.) Research Handbook on Digital Transformations. Cheltenham: Edward Elgar 225-253 (2015) https://dx.doi.org/10.4337/9781784717766.00019; Yermack, D. "Corporate Governance and Blockchains," Review of Finance 21.1 7-31 (2017) https: //dx. doi .org/10.1093/rof/rfw074

${ }^{4}$ Davidson, S., de Filippi, P., Potts, J. "Blockchains and the Economic Institutions of Capitalism," Journal of Institutional Economics (forthcoming); Berg, C., Davidson, S., Potts, J. "The Blockchain Economy: a beginner's guide to institutional cryptoeconomics," Medium (27 September 2017) https://medium.com/ @eryptoeconomics/the-blockchain-economy-a-beginners-guide-toinstitutional-cryptoeconomics-64bf $2 \mathrm{f} 2 \mathrm{beec} 4$; Berg, C., Davidson, S., Potts, J. "Institutional Cryptoeconomics: A New Model for a New Century," CoinDesk (16 September 2017)

https://www.coindesk.com/institutional-cryptoeconomics/; Berg, C., Davidson, S., Potts, J. "What is a token?" Presentation at Crypto Economics Security Conference, Blockchain at Berkeley (2 October 2017) http://files.ozblogistan.com.au/sites/4/2017/10/03101044/what-is-a-token.pptx; Berg, C., Davidson, S., Potts, J. “The Institutional Economics of Identity,” SSRN (16 November 2017) https://papers.ssrn.com/sol3/papers.cfm?abstract_id=3072823; Berg, C., Davidson, S., Potts, J. "Blockchains industrialise trust," SSRN (21 November 2017) https://papers.ssrn.com/sol3/papers.cfm?abstract_id=3074070

${ }^{5}$ Coase, R. "The nature of the firm," Economica $4.16386-405$ (1937); Coase, R. "The problem of social cost" Journal of Law and Economics 3 1-44 (1960); Williamson, O. "Transaction cost economics: the governance of contractual relations," Journal of Law and Economics 22.2 233-61 (1979); Williamson, O. The Economic Institutions of Capitalism. New York: Free Press (1985)

${ }^{6}$ Reijers, W., O'Brolcháin, F., Haynes, P. "Governance in Blockchain Technologies \& Social Contract Theories," Ledger 1 134-151 (2016) https://dx.doi.org/10.5195/LEDGER.2016.62; Kavanagh, D., Miscione, G. "Bitcoin and the Blockchain: A coup d'état in Digital Heterotopia?" in Critical Management Studies Conference. Leicester (2015) https: //dx.doi.org/10.2139/ssrn. 2624922

${ }^{7}$ Jönsson, C., Hall, M. Essence of Diplomacy. United Kingdom: Palgrave Macmillan 45-50 (2005)

${ }^{8}$ Güner, S., Druckman, D. "Identification of a Princess under Incomplete Information: An Amarna Story," Theory and Decision 48.4 383-407 (2000) https : //doi.org/10.1023/A: 1005205315505

${ }^{9}$ Morris, E. F. "Bowing and Scraping in the Ancient near East: An Investigation into Obsequiousness in the Amarna Letters," Journal of Near Eastern Studies 65.3 179-196 (2006); Cohen, R. "All in the Family: Ancient near Eastern Diplomacy," International Negotiation 1.1 11-28 (1996)

https://dx.doi.org/10.1086/508575

${ }^{10}$ Michalowski, P. "Sumerian Literature: An Overview," in J. Sasson (Ed.) Civilizations of the Ancient Near East. New York: Scribner 2284-85 (1995).

${ }^{11}$ Lamberg-Karlovsky, C. C. "To Write or Not to Write," in T. Potts, M. Roaf, D. Stein (Eds.) Culture through Objects: Ancient Near Eastern studies in honour of P. R. S. Moorey. Oxford: Griffith Institute, 5975 (2003); Costello, S. K., "Image, Memory and Ritual: Re-viewing the Antecedents of Writing," Cambridge Archaeological Journal 21.2 247-62 (2011); Matthews, R. "Writing (and Reading) as Material Practice: The world of cuneiform culture as an arena for investigation," in K. E. Piquette, R. D. Whitehouse (Eds.) Writing as Material Practice: Substance, surface and medium London: Ubiquity Press 65-74 (2013).

${ }^{12}$ Michalowski, P., Reiner, E. Letters from Early Mesopotamia. Atlanta, Georgia: Scholars Press 2-3 (1993). 
${ }^{13}$ Zaccagnini, C. "Ideological and Procedural Paradigms in Ancient near Eastern Long Distance Exchanges: The Case of Enmerkar and the Lord of Aratta," Altorientalische Forschungen 20.1 34-42 (1993)

https : //doi.org/10.1524/aofo.1993.20.1.34

${ }^{14}$ Cohen, S. Enmerkar and the Lord of Aratta (PhD thesis). University of Pennsylvania 38-39 (1974)

${ }^{15}$ Cooper, J. S., Heimpel, W. "The Sumerian Sargon Legend," Journal of the American Oriental Society

103.1 67-82 (1983) https://doi.org/10.2307/601860

${ }^{16}$ Alster, B. "A note on the Uriah Letter in the Sumarian Sargon Legend," Zeitschrift fur Assyriologie 77

169-73 (1987) https://doi.org/10.1515/zava.1987.77.2.169

${ }^{17}$ Michalowski, P., Reiner, E. Letters from Early Mesopotamia. 3

${ }^{18}$ Ibid.

${ }^{19}$ Podany, A.H. Brotherhood of Kings: How International Relations Shaped the Ancient near East. 10, 89

${ }^{20}$ Michalowski, Reiner, Letters from Early Mesopotamia. 13-14

${ }^{21}$ Podany, A.H. Brotherhood of Kings: How International Relations Shaped the Ancient near East. 194

${ }^{22}$ Kinship diplomacy was also a feature of Greek and Roman international relations, see Jones, C. P. Kinship Diplomacy in the Ancient World. Cambridge, Massachusetts and London: Harvard University Press (1999)

${ }^{23}$ Podany, A. H. Brotherhood of Kings: How International Relations Shaped the Ancient near East. 79

${ }^{24}$ Podany, A. H. "Preventing Rebellion Through the Creation of Symbolic Ties of Kinship," in S. Richardson (Ed.) Rebellions and Peripheries in the Cuneiform World. Connecticut: American Oriental Society 47-74 (2010)

${ }^{25}$ Kertzer, D. I. Ritual, Politics, and Power. New Haven and London: Yale University Press (1988)

${ }^{26}$ Iannaccone, L. R. "Sacrifice and Stigma: Reducing Free-riding in Cults, Communes, and Other Collectives," Journal of Political Economy 100.2 271-291 (1992). For the relationship between ritual and costly signaling, see Bliege Bird, R., Smith, E. A. "Signaling theory, strategic interaction, and symbolic capital," Current Anthropology 46.2 222-248 (2005); Sosis, R. "Why aren't we all Hutterites? Costly signaling theory and religious behavior," Human Nature 14.2 91-127 (2003)

${ }^{27}$ Jönsson, C., Hall, M. Essence of Diplomacy. 48

${ }^{28}$ Jönsson, C. "Diplomatic Signaling in the Amarna Letters," in R. Cohen, R. Westbrook (Eds.) Amarna Diplomacy: The Beginnings of International Relations Baltimore and London: Johns Hopkins University Press 191-204 (2000)

${ }^{29}$ Morris, E. F. "Bowing and Scraping in the Ancient near East: An Investigation into Obsequiousness in the Amarna Letters." Journal of Near Eastern Studies 65.3 179-196 (2006) https : //doi .org/10.1086/508575

${ }^{30}$ Podany, A.H. Brotherhood of Kings: How International Relations Shaped the Ancient near East. 80-81

${ }^{31}$ Aste, T. "The Fair Cost of Bitcoin Proof of Work," SSRN (27 June 2016)

https : //dx.doi.org/10.2139/ssrn.2801048

${ }^{32}$ No Author. "Problems," Ethereum Wiki (accessed 6 October 2017)

https://github.com/ethereum/wiki/wiki/Problems

${ }^{33}$ Buterin, V. “A Proof of Stake Design Philosophy,” Medium (31 December 2016)

https://medium.com/@VitalikButerin/a-proof-of-stake-design-philosophy-506585978d51

${ }^{34}$ Biggs, R. D. "Ebla Texts," in Freedman D. N. (Ed.) Anchor Bible Dictionary. New York: Doubleday 263$270(1992)$ 
${ }^{35}$ Beckman, G. Hittite Diplomatic Texts. Atlanta, Georgia: Scholars Press. 3 (1999)

${ }^{36}$ Altman, A. "The Role of the 'Historical Prologue' in the Hittite Vassal Treaties: An Early Experiment in Securing Treaty Compliance," Journal of the History of International Law 6.1 43-63 (2004)

https://doi.org/10.1163/157180504773805838

${ }^{37}$ Davidson, S. de Filippi, P., Potts, J. "Blockchains and the Economic Institutions of Capitalism."

${ }^{38}$ Ibid.

${ }^{39}$ Djankov, S., Glaeser, E., La Porta, R., Lopez-de-Silanes, F., Shleifer, A. "The New Comparative Economics," Journal of Comparative Economics 31.4 595-619 (2003)

https://doi.org/10.1016/j.jce.2003.08.005

${ }^{40}$ Podany, A.H. Brotherhood of Kings: How International Relations Shaped the Ancient near East. 161

${ }^{41}$ Williamson, O. The Economic Institutions of Capitalism. New York: The Free Press (1985)

${ }^{42}$ Liverani, M. International Relations in the Ancient near East, 1600-1100 BC. Basingstoke and New York: Palgrave Macmillan 124 (2001)

${ }^{43}$ Ibid.

${ }^{44}$ Podany, A.H. Brotherhood of Kings: How International Relations Shaped the Ancient near East. 172

${ }^{45}$ Davidson, S. de Filippi, P., Potts, J. "Blockchains and the Economic Institutions of Capitalism"; Berg, C., Davidson, S., Potts, J. "Blockchains industrialise trust."

${ }^{46}$ Berg, C., Davidson, S., Potts, J. ibid.

(c) $B Y$

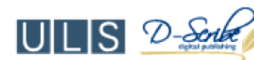

Articles in this journal are licensed under a Creative Commons Attribution 4.0 License.

Ledger is published by the University Library System of the University of Pittsburgh as part of its D-Scribe Digital Publishing Program and is cosponsored by the University of Pittsburgh Press. 